\title{
WITHDRAWAL OF MAINTENANCE THERAPY FOR CYTOMEGALOVIRUS RETINITIS IN AIDS PATIENTS EXHIBITING IMMUNOLOGICAL RESPONSE TO HAART
}

\author{
Luis Fernando WAIB(1), Sandra Helena Alves BONON(1), Angela Christina SALLES(2), Gil BENARD(3), Augusto César Penalva de OLIVEIRA(1),
} Claudio Sergio PANNUTI(4), Rogério de Jesus PEDRO(1) \& Sandra Cecília Botelho COSTA(1)

\begin{abstract}
SUMMARY
Background: Before the introduction of highly active antiretroviral therapy (HAART), CMV retinitis was a common complication in patients with advanced HIV disease and the therapy was well established; it consisted of an induction phase to control the infection with ganciclovir, followed by a lifelong maintenance phase to avoid or delay relapses. Methods: To determine the safety of CMV maintenance therapy withdrawal in patients with immune recovery after HAART, 35 patients with treated CMV retinitis, on maintenance therapy, with CD4+ cell count greater than 100 cells $/ \mathrm{mm}^{3}$ for at least three months, but almost all patients presented these values for more than six months and viral load $<30000$ copies $/ \mathrm{mL}$, were prospectively evaluated for the recurrence of CMV disease. Maintenance therapy was withdrawal at inclusion, and patients were monitored for at least 48 weeks by clinical and ophthalmologic evaluations, and by determination of CMV viremia markers (antigenemia-pp65), CD4+/CD8+ counts and plasma HIV RNA levels. Lymphoproliferative assays were performed on 26/35 patients. Results: From 35 patients included, only one had confirmed reactivation of CMV retinitis, at day 120 of follow-up. No patient returned positive antigenemia tests. No correlation between lymphoproliferative assays and CD4+ counts was observed. Conclusion: CMV retinitis maintenance therapy discontinuation is safe for those patients with quantitative immune recovery after HAART.
\end{abstract}

KEYWORDS: Cytomegalovirus; HAART; AIDS; CMV retinitis.

\section{INTRODUCTION}

Cytomegalovirus (CMV) disease is an important cause of morbidity and mortality in AIDS patients. In the pre-HAART era, CMV retinitis was the most common HIV-associated retinopathy, occurring in 20$40 \%$ of patients. Median time to progression was 47 to 104 days, mean survival after diagnosis was six to 10 months, and indefinite intravenous maintenance therapy was mandatory ${ }^{12}$. It leads to blindness in nearly all untreated cases, has a high rate of short-term relapse and is strongly associated with higher mortality ${ }^{1,10,15,17,34,38}$.

In the HAART era the incidence of CMV retinitis has declined $80 \%$ and survival after diagnosis has increased to over one year ${ }^{12}$.

After the development of HAART and subsequent successful HIV suppression and sustained increase in CD4+ cell counts, studies characterizing the effects of immune recovery on the course of opportunistic infections were initiated. Studies addressing CMV immune recovery were first published in $1998^{24,31,44}$ targeting both humoral $^{6}$ and cellular responses ${ }^{23}$. Clinical studies followed, demonstrating a low incidence of recurrence after withdrawal of secondary prophylaxis in small samples, 5,7,19,25,30,32,36,41,45,46.
The primary objective of the present open, non-randomized, prospective and multicenter study is to evaluate the safety of the withdrawal of secondary CMV prophylaxis in AIDS patients with treated CMV retinitis who exhibit a sustained immunological response to HAART $\left(\mathrm{CD} 4+\right.$ count $>100$ cells $/ \mathrm{mm}^{3}$ and Viral Load $<30,000$ copies $/ \mathrm{mm}^{3}$ ), together with negative antigenemia tests for at least three months. A second objective was to evaluate the utility of antigenemia to monitor the recurrence of CMV disease, comparing the test results with clinical and ophthalmologic data.

The protocol was designed in accordance with the requirements for "Research Involving Human Subjects" in Brazil, and approved by the Research Ethics Committee of each participating institution. All patients provided written informed consent.

\section{PATIENTS AND METHODS}

Patients: Patients included in this protocol were originally treated at the following facilities: 1. AIDS Day-Hospital, UNICAMP Campinas State University (Campinas, Brazil); 2. Day-Hospital, AIDS Facility of Campinas City (Campinas, Brazil); 3. AIDS Day-Hospital, IIER - Emilio Ribas Infectious Diseases Institute (São Paulo, Brazil); 


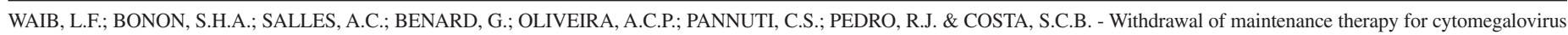
retinitis in AIDS patients exhibiting immunological response to HAART. Rev. Inst. Med. trop. S. Paulo, 49(4):215-219, 2007.

and 4. Day-Hospital, CRTA - Reference and Training Center for Sexually Transmitted Diseases and AIDS (São Paulo, Brazil).

Inclusion criteria were: AIDS patients receiving HAART (two nucleoside analogues plus one or two proteases inhibitors) with previously treated CMV retinitis receiving secondary prophylaxis, exhibiting sustained (quantitative) immune recovery, characterized by CD4+ counts greater than 100 cells $/ \mathrm{mm}^{3}$ for at least three months prior to inclusion, with a viral load of less than 30,000 copies $/ \mathrm{mm}^{3(2,6,10,33,41,45)}$.

Exclusion criteria were: Patients with ganciclovir eye implants; patients with any retinal condition that might interfere with their ophthalmologic evaluation, such as Toxoplasma gondii retinitis or cataract; patients with previous CMV retinal infection at perimacular or peripapillary sites due to the risk of rapid visual loss; patients requiring oncological chemotherapy and/or radiation therapy; patients with any other condition constituting a high risk of death in the first two months of the protocol; patients undergoing therapy for active CMV disease were excluded until clinical status was stable; patients unable to fully understand the terms of the consent to treatment.

\section{Laboratory Techniques}

CMV Antigenemia (pp65): Antigenemia ( $p p 65)$ tests were performed every 15 days for the first two months after ganciclovir withdrawal and monthly thereafter.

The same in-house protocol and reagents were used in the laboratories of all participating institutions to provide comparable results $^{3}$. The sequence described by VAN DER BIJ et al..$^{42}$ was performed with the following modifications: (1) Cells were fixed in acetone; (2) Cell counts were considered to be the number of positive cells per $3 \times 10^{5}$ cells $^{13,28}$.

For the purposes of exclusion from the protocol and endpoints, any positive test was considered, regardless of the number of positive cells. Two consecutive positive tests were interpreted as persistent viremia, and therefore, as constituting laboratory endpoint.

CD4+/CD8+ Lymphocyte Subpopulation Counts: Lymphocyte subpopulation counts were performed according to the Brazilian AIDS Consensus, every 3-4 months. Additional measurements were obtained as necessary. Beckton-Dickinson flow cytometry kits were used with FacsCount devices to perform this test.

HIV-1 Viral Load: HIV-1 viral loads were performed every 3-4 months, according to the Brazilian AIDS Consensus. Additional measurements were obtained when necessary. Viral load testing was performed using Nuclisense Biolab ${ }^{\circledR}$ (NASBA), which has a lower limit of detection of 40 copies $/ \mathrm{mm}^{3}$, according to the manufacturer's instructions.

Lymphoproliferative assays: Lymphoproliferative assays were performed at least once during the study. As this assay did not constitute part of our initial protocol, this analysis was not conducted on every patient. Proliferation indexes equal to or greater than 3.0 were considered positive.
In those patients returning negative results, an additional test was performed after at least three months.

Endpoints: Laboratory endpoints were considered to consist of two consecutive, positive, antigenemia tests or a decrease in CD4+ counts to less than 100 cells $/ \mathrm{mm}^{3}$. Clinical endpoints constituted clinical features suggestive of active CMV infection, requiring therapy with ganciclovir or foscarnet despite antigenemia test results.

\section{RESULTS}

Thirty-five patients were included in the study. Twenty-six (74\%) were male. Mean age was 37.2 years (range 27-57, median 36 years). Mean time elapsed from CD4+ recovery until inclusion in the protocol was 454.3 days (range 92-1038, median 307 days). The median followup time was 386.5 days (range 96-504). No follow-up was less than 360 days, except for those cases who met the endpoint criteria.

The mean CD4+ count at the startpoint was 278 cells $/ \mathrm{mm}^{3}$ (range 112-684). At the end of follow-up, the mean CD4+ count was 342 cells $/ \mathrm{mm}^{3}$ (range 113-755). The mean increase in CD4+ counts during prophylaxis withdrawal was 62 cells $/ \mathrm{mm}^{3}$.

Recurrence of CMV disease and other events: Two patients (A and B) exhibited progressive neurological disease with CD4+ counts greater than 100 cells $/ \mathrm{mm}^{3}$ as described below:

On day 120 of follow-up, Patient A presented progressive polyradiculopathy and typical CMV retinitis that led to a clinical diagnosis of CMV disease, despite negative antigenemia tests and negative PCR results performed on the cerebrospinal fluid. After ganciclovir treatment, this patient recovered completely. Lymphoproliferative assays were negative, indicating the absence of a specific response to CMV. The CD4+ count at the time of recurrence was 195 cells $/ \mathrm{mm}^{3}$.

Patient B presented fever and progressive polyradiculopathy on day 96 of follow-up. Therapy with ganciclovir was promptly initiated, despite negative antigenemia test results. CMV-PCR testing in the cerebrospinal fluid was performed two weeks after the initial evaluation, yielding negative results. Lymphoproliferative assays were negative, while the CD4+ count at disease onset was 181 cells $/ \mathrm{mm}^{3}$. Despite aggressive treatment, the patient died before a definitive diagnosis was established. No autopsy was performed in the patient.

One patient exhibited ophthalmological features compatible with immune recovery vitritis (IRV) at day 322 of follow-up (739 days after HAART), but within two weeks evolved to complete recovery with no need for corticosteroid treatment. CD4+ count at the onset of vitritis was 336 cells $/ \mathrm{mm}^{3}$, and the lymphoproliferative assay performed on day 14 of follow up was positive (proliferation index $=3.0$ ).

One patient presented a sustained decrease in CD4+ counts less than 100 cells $/ \mathrm{mm}^{3}$ starting on day 237 of follow-up, and was excluded from the study. Nevertheless, this patient was observed receiving CMV prophylaxis, and displayed no evidence of relapse. Lymphoproliferative assays were negative (proliferation index $=2.0$ ) at the time of exclusion. The CD4+ count at the end of the observation period was 159 cells $/ \mathrm{mm}^{3}$. 


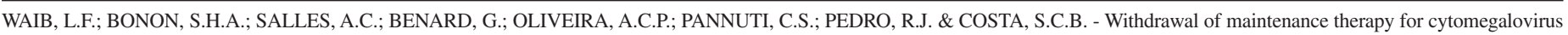
retinitis in AIDS patients exhibiting immunological response to HAART. Rev. Inst. Med. trop. S. Paulo, 49(4):215-219, 2007.

Antigenemia Tests: No patient returned a positive antigenemia test during the study.

Lymphoproliferative Assays (LPA): Lymphoproliferative assays were performed on only 26 of the initial 35 patients. The proliferation index was greater than 3.0 in fifteen patients (57\%) and below this value in eleven patients. For the responders, the mean proliferation index was 22.8 (range $3.0-154.9$ ).

There was no correlation between LPA results and any other immunological parameter measured. This included CD4+ and CD8+ counts before HAART, CD4+ and CD8+ counts before entrance to the protocol, CD4+ and CD8+ counts at time of the LPA assay, CD4+ and $\mathrm{CD} 8+$ counts at the end of the follow-up period, CD4+ to CD8+ ratio (end of the follow-up period/pre-HAART), CD4+ and CD8+ difference (end of the follow up-pre-HAART), and time elapsed with CD4+ counts above 100 cells $/ \mathrm{mm}^{3}$ until LPA was performed.

\section{DISCUSSION}

We found no evidence that antigenemia could predict the reactivation of CMV disease in this study.

This method can be used to identify patients with a wide variety of clinical syndromes of CMV disease in HIV patients, including retinitis, gastrointestinal diseases; hepatobiliary diseases; encephalitis and other neurological diseases; pneumonia and adrenalitis? .

The only patient with reactivated retinitis confirmed did not return positive antigenemia during the follow-up period. The CMV disease in this patient may have been due to local reactivation, rather than systemic dissemination ${ }^{39}$. This mechanism of reactivation is not well understood, but there is some evidence that the vascular endothelium of the eye is not permeable to immune effector cells ${ }^{18,35}$.

Of our 35 patients, $57 \%$ were responders in $\mathrm{CMV}$ lymphoproliferative assays. This is approximately the same as reported by GERNA et al. ${ }^{11}$. However, among the 11 (43\%) non-responders, only one showed CMV relapse during follow-up. Similarly to previously published data, we found no correlation between lymphoproliferative assays (LPA) and total CD4+ and CD8+ counts at baseline, at protocol inclusion, at the time of LPA assay, at the end of follow-up, and the period in which CD4+ counts were greater than 100 cells $/ \mathrm{mm}^{3}$. The discrepancy between specific CD4+ response and LPA has been described in two previous studies. PICCININI et al. ${ }^{29}$ reported some discordance between lymphoproliferative responses and the presence of CMV-specific CD4+ cells in AIDS patients ${ }^{29}$. KEANE et al. ${ }^{22}$, comparing LPA and ELISpot, found a better correlation between the latter and the presence of CMV-reactive $\mathrm{T}$ cells ${ }^{22}$. Neither technique, detection of CMV-specific CD4+ cells or ELISpot, has been evaluated for detecting those patients at risk of CMV disease relapse in this setting so far.

Discontinuing CMV secondary prophylaxis required close clinical follow-up in which laboratory data are not helpful in predicting reactivation or new CMV disease. However, this careful follow-up is not more costly than the regular follow-up necessary for HIV-infected individuals presenting severe immunological damage.
We encountered only one case of IRV, in contrast to the situation reported by KARAVELLAS et al. ${ }^{21}$. In this patient there was an important increase in CD4+ count $\left(126\right.$ cells $/ \mathrm{mm}^{3}$ before HAART to 336 cells $/ \mathrm{mm}^{3}$ during the onset of IRV) as described by JABS et al. ${ }^{16}$. This case of IRV occurred later in the course of immune recovery than has been previously described ${ }^{14,21}$, suggesting that this event might occur even in patients showing long-term CD4+ response to HAART therapy.

Due to the low recurrence of CMV disease, we conclude, as previous literature reports suggest, that the withdrawal of CMV prophylaxis is a safe procedure in patients on HAART showing immune recovery $2,5,20,25,26,30,36,40,41,43,45$.

Clinical demonstration of the impact of HAART on the natural history of AIDS has been one of the most significant steps towards a more complete comprehension of this disease. In the post-HAART era, we have witnessed an important decrease in CMV disease incidence among AIDS patients $4,8,27,33,46$. However, CMV infection remains an event associated with high morbidity and mortality rates, justifying every effort to understand the interaction between the virus and its host.

\section{RESUMO}

Retirada da terapia de manutenção para retinite por citomegalovírus em pacientes com aids exibindo resposta imunológica à terapia anti-retroviral altamente efetiva (HAART)

Antes da introdução da terapia anti-retroviral altamente efetiva (HAART), a retinite por CMV era uma complicação comum em pacientes com doença por HIV avançada e a terapia era bem estabelecida e consistia em uma fase de indução com ganciclovir para controlar a infecção, seguida por uma manutenção por toda a vida, para evitar e retardar as recidivas. Para determinar a segurança da retirada da terapia de manutenção para retinite por citomegalovírus em pacientes com recuperação imunológica após o HAART, 35 pacientes com retinite por CMV tratados com terapia de manutenção, com contagem de células CD4+ maiores que 100 células $/ \mathrm{mm}^{3}$ por no mínimo três meses, mas a maioria dos pacientes apresentava esses valores por mais de seis meses e carga viral $<30.000$ cópias $/ \mathrm{mL}$, foram avaliados prospectivamente para a recorrência de doença por CMV. A terapia de manutenção foi retirada na inclusão e os pacientes foram monitorados no mínimo 48 semanas por avaliações clínicas e oftalmológicas e pela determinação de marcadores de viremia para CMV (antigenemia). Contagens de CD4+ e CD8+ e níveis de RNA de HIV no plasma. Métodos linfoproliferativos foram realizados em 26/ 35 pacientes. Resultados: Dos 35 pacientes incluídos no estudo, somente um teve reativação da retinite por CMV confirmada, no dia 120 do seguimento. Nenhum paciente teve testes de antigenemia positivos. Nenhuma correlação entre os ensaios linfoproliferativos e contagens de CD4+ foi observada. Conclusão: Descontinuação da terapia de manutenção para retinite por CMV é segura para aqueles pacientes com recuperação imune quantitativa após HAART.

\section{ACKNOWLEDGEMENTS}

We would like to thank Lucy Santos Villas-Boas (LIM-HC/USP) for antigenemia tests; Marcina Garcia and Silvia Maria Wenzel Garcia (UNICAMP) for viral loads and lymphocyte subpopulation counts. 


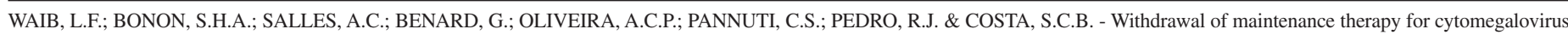
retinitis in AIDS patients exhibiting immunological response to HAART. Rev. Inst. Med. trop. S. Paulo, 49(4):215-219, 2007.

\section{REFERENCES}

1. ACTG - Mortality in patients with the acquired immunodeficiency syndrome treated with either foscarnet or ganciclovir for cytomegalovirus retinitis. Studies of Ocular Complications of AIDS Research Group, in collaboration with the AIDS Clinical Trials Group. New Engl. J. Med., 326: 213-220, 1992.

2. BERENGUER, J.; GONZALEZ, J.; PULIDO, J. et al. - Discontinuation of secondary prophylaxis in patients with cytomegalovirus retinitis who have responded to highly active antiretroviral therapy. Clin. infect. Dis., 34: 394-397, 2002.

3. BONON, S.H.; MENONI, S.M.F.; ROSSI, C.L. et al. - Surveillance of cytomegalovirus infection in haematopoietic stem cell transplantation patients. J. Infect., 50: 130137, 2005.

4. CASSOUX, N.; BODAGHI, B.; KATLAMA, C. \& LEHOANG, P. - CMV retinitis in the era of HAART. Ocul. Immunol. Inflamm., 7: 231-235, 1999.

5. CURI, A.L.; MURALHA, A.; MURALHA, L. \& PAVESIO, C. - Suspension of anticytomegalovirus maintenance therapy following immune recovery due to highly active antiretroviral therapy. Brit. J. Ophthal., 85: 471-473, 2001.

6. DEAYTON, J.; WILSON, J.R.; SABIN, P. et al. - Recovery of antibody responses to Cytomegalovirus (CMV) Glycoprotein B ( $\mathrm{gB}$ ) following Highly Active Antiretroviral Therapy (HAART). In: CONFERENCE ON RETROVIRUSES AND OPPORTUNISTIC INFECTIONS, 6., Chicago, 1999. p. 153.

7. DEAYTON, J.R.; WILSON, P.; SABIN, C. et al. - Changes in the natural history of cytomegalovirus retinitis following the introduction of highly active antiretroviral therapy. Aids, 14: 1163-1670, 2000.

8. DEGREZIA, M.G. \& ROBINSON, M. - Ophthalmic manifestations of HIV: an update. J. Ass. Nurses AIDS Care, 12: 22-32, 2001.

9. FRANCISCI, D.; TOSTI, A.; PREZIOSI, R. et al. - Role of antigenemia assay in the early diagnosis and prediction of human cytomegalovirus organ involvement in AIDS patients. Europ. J. clin. Microbiol. infect. Dis., 14: 498-503, 1995.

10. GALLANT, J.E.; MOORE, R.D.; RICHMAN, D.D.; KERULY, J. \& CHAISSON, R.E. Incidence and natural history of cytomegalovirus disease in patients with advanced human immunodeficiency virus disease treated with zidovudine. The Zidovudine Epidemiology Study Group. J. infect. Dis., 166: 1223-1227, 1992.

11. GERNA, G.; PICCININI, G.; GENINI, E. et al. - Declining levels of rescued lymphoproliferative response to human cytomegalovirus (HCMV) in AIDS patients with or without HCMV disease following long-term HAART. J. acquir. immune Defic. Syndr., 28: 320-331, 2001.

12. GOLDBERG, D.E.; SMITHEN, L.M.; ANGELILLI, A. \& FREEMAN, W.R. - HIVassociated retinopathy in the HAART era. Retina, 25: 633-649, 2005.

13. HALWACHS, G.; ZACH, G.; POGGLITSCH, H. et al. - A rapid immunocytochemical assay for CMV detection in peripheral blood of organ-transplanted patients in clinical practice. Transplantation, 56: 338-342, 1993.

14. HENDERSON, H.W. \& MITCHELL, S.M. - Treatment of immune recovery vitritis with local steroids. Brit. J. Ophthal., 83: 540-545, 1999.

15. HOOVER, D.R.; PENG, Y.; SAAH, A. et al. - Occurrence of cytomegalovirus retinitis after human immunodeficiency virus immunosuppression. Arch. Ophthal., 114: $821-827,1996$

16. JABS, D.A.; VAN NATTA, M.L.; KEMPEN, M.L. et al. - Characteristics of patients with cytomegalovirus retinitis in the era of highly active antiretroviral therapy. Amer. J. Ophthal., 133: 48-61, 2002.

17. JACOBSON, M.A. - Treatment of cytomegalovirus retinitis in patients with the acquired immunodeficiency syndrome. New Engl. J. Med., 337: 105-114, 1997.
18. JACOBSON, M.A.; ZEGANS, M.A.; PAVAN, M. et al. - Cytomegalovirus retinitis after initiation of highly active antiretroviral therapy. Lancet, 349: 1443-1445, 1997.

19. JOUAN, M.; SAVES, M.; TUBIANA, M. et al. - A prospective multicentre study to evaluate the discontinuation of maintenance therapy for CMV Retinitis in HIVpatients receiving HAART. In: CONFERENCE ON RETROVIRUSES AND OPPORTUNISTIC INFECTIONS, 6., Chicago, 1999

20. JOUAN, M.; SAVES, M.; TUBIANA, M. et al. - Discontinuation of maintenance therapy for cytomegalovirus retinitis in HIV-infected patients receiving highly active antiretroviral therapy. Aids, 15: 23-31, 2001.

21. KARAVELLAS, M.P.; PLUMMER, M.P.; MACDONALD, D.J. et al. - Incidence of immune recovery vitritis in cytomegalovirus retinitis patients following institution of successful highly active antiretroviral therapy. J. infect. Dis., 179: 697-700, 1999.

22. KEANE, N.M.; PRICE, P.; STONE, S.F. et al. - Assessment of immune function by lymphoproliferation underestimates lymphocyte functional capacity in HIV patients treated with highly active antiretroviral therapy. AIDS Res. hum. Retroviruses, 16: 1991-1996, 2000.

23. LI, T.S.; TUBIANA, R.; KATLAMA, C. et al. - Long-lasting recovery in CD4 T-cell function and viral-load reduction after highly active antiretroviral therapy in advanced HIV-1 disease. Lancet, 351: 1682-1686, 1998.

24. MACDONALD, J.C.; KARAVELLAS, M.P.; TORRIANI, F.J. et al. - Highly active antiretroviral therapy-related immune recovery in AIDS patients with cytomegalovirus retinitis. Ophthalmology, 107: 877-881, 2000.

25. MACDONALD, J.C.; TORRIANI, F.J.; MORSE, L.S. et al. - Lack of reactivation of cytomegalovirus (CMV) retinitis after stopping CMV maintenance therapy in AIDS patients with sustained elevations in CD4 T cells in response to highly active antiretroviral therapy. J. infect. Dis., 177: 1182-1187, 1998.

26. MARGOLIS, T.P. - Discontinuation of anticytomegalovirus therapy in patients with HIV infection and cytomegalovirus retinitis. Surv. Ophthal., 44: 455, 2000.

27. MITCHELL, S.M.; MEMBREY, W.L.; YOULE, M.S. et al. - Cytomegalovirus retinitis after the initiation of highly active antiretroviral therapy: a 2-year prospective study. Brit. J. Ophthal., 83: 652-655, 1999.

28. PANNUTI, C.S.; KALLAS, E.G.; MUCCIOLI, C. et al. - Cytomegalovirus antigenemia in acquired immunodeficiency syndrome patients with untreated cytomegalovirus retinitis. Amer. J. Ophthal., 122: 847-852, 1996.

29. PICCININI, G.; COMOLLI, G.; GENINI, G. et al. - Comparative analysis of human cytomegalovirus-specific CD4(+) T-cell frequency and lymphoproliferative response in human immunodeficiency virus-positive patients. Clin. diagn. Lab. Immunol., 8: $1225-1230,2001$.

30. POSTELMANS, L.; GERARD, M.; SOMMEREIJNS, B. \& CASPERS-VELU, L. Discontinuation of maintenance therapy for CMV retinitis in AIDS patients on highly active antiretroviral therapy. Ocul. Immunol. Inflamm., 7: 199-203, 1999.

31. POWDERLY, W.G., LANDAY, A. \& LEDERMAN, M.M. - Recovery of the immune system with antiretroviral therapy: the end of opportunism? J. Amer. med. Ass., 280: 72-77, 1998.

32. RUHSWURM, I.; RIES, I.; KREPLER, E. et al. - Control of cytomegalovirus retinitis after combination antiretroviral therapy. Acta Ophthal. Scand., 77: 471-473, 1999.

33. SALMON-CERON, D. - Cytomegalovirus infection: the point in 2001. HIV Med., 2: 255-259, 2001.

34. SMITH, M.A. \& BRENNESSEL, D.J. - Cytomegalovirus. Infect. Dis. Clin. N. Amer., 8: $427-438,1994$.

35. SODERBERG-NAUCLER, C. \& NELSON, J.Y. - Human cytomegalovirus latency and reactivation - a delicate balance between the virus and its host's immune system. Intervirology, 42: 314-321, 1999. 


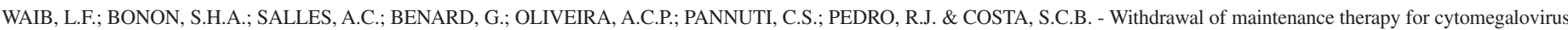
retinitis in AIDS patients exhibiting immunological response to HAART. Rev. Inst. Med. trop. S. Paulo, 49(4):215-219, 2007.

36. SORIANO, V; DONA, C.; RODRIGUEZ-ROSADO, R.; BARREIRO, P. \& GONZALEZ LAHOZ, J. - Discontinuation of secondary prophylaxis for opportunistic infections in HIV-infected patients receiving highly active antiretroviral therapy. Aids, 14: 383 $386,2000$.

37. STEININGER, C.; PUCHHAMMER-STOCKL, E. \& POPOW-KRAUPP, T. Cytomegalovirus disease in the era of highly active antiretroviral therapy (HAART). J. clin. Virol., 37: 1-9, 2006.

38. TAY-KEARNEY, M.L. \& JABS, D.A. - Ophthalmic complications of HIV infection Med. Clin. N. Amer., 80: 1471-1492, 1996.

39. TUFAIL, A.; MOE, A.A.; MILLER, M.J. et al. - Quantitative cytomegalovirus DNA level in the blood and its relationship to cytomegalovirus retinitis in patients with acquired immune deficiency syndrome. Ophthalmology, 106: 133-141, 1999.

40. TURAL, C.; ROMEU, C.; SIRERA, J. et al. - A 24 month follow-up of cytomegalovirus retinitis without secondary prophylaxis following highly active antiretroviral therapy. In: CONFERENCE ON RETROVIRUSES AND OPPORTUNISTIC INFECTIONS, 6., Chicago, 1999. p. 153 (Abstract no. 455).

41. TURAL, C.; ROMEU, J.; SIRERA, J. et al. - Long-lasting remission of cytomegalovirus retinitis without maintenance therapy in human immunodeficiency virus-infected patients. J. infect. Dis., 177: 1080-1083, 1998.
42. VAN DER BIJ, W.; VAN SON, W.J.; VAN DER BERG, A.P. et al. - Cytomegalovirus (CMV) antigenemia: rapid diagnosis and relationship with CMV-associated clinical syndromes in renal allograft recipients. Transplant. Proc., 21: 2061-2064, 1989.

43. VRABEC, T.R.; BALDASSANO, V.F. \& WHITCUP, S.M. - Discontinuation of maintenance therapy in patients with quiescent cytomegalovirus retinitis and elevated CD4+ counts. Ophthalmology, 105: 1259-1264, 1998.

44. WEINBERG, A.; WOHL, D.A.; BARRETT, R.J. \& VAN DER HORST, C. -Inconsistent reconstitution of cytomegalovirus-specific cell-mediated immunity in human immunodeficiency virus-infected patients receiving highly active antiretroviral therapy. J. infect. Dis., 184: 707-712, 2001.

45. WHITCUP, S.M.; FORTIN, E.; LINDBLAD, A.S. et al. - Discontinuation of anticytomegalovirus therapy in patients with HIV infection and cytomegalovirus retinitis. J. Amer. med. Ass., 282: 1633-1637, 1999.

46. WOHL, D.A.; KENDALL, M.A.; OWENS, S. et al. - The safety of discontinuation of maintenance therapy for cytomegalovirus (CMV) retinitis and incidence of immune recovery uveitis following potent antiretroviral therapy. HIV clin. Trials, 6: 136$146,2005$.

Received: 3 April 2006

Accepted: 15 January 2007 